The following resources related to this article are available online at www.sciencemag.org (this information is current as of November 9, 2009 ):

Updated information and services, including high-resolution figures, can be found in the online version of this article at:

http://www.sciencemag.org/cgi/content/full/314/5798/479

Supporting Online Material can be found at:

http://www.sciencemag.org/cgi/content/full/314/5798/479/DC1

This article cites $\mathbf{2 4}$ articles, 8 of which can be accessed for free:

http://www.sciencemag.org/cgi/content/full/314/5798/479\#otherarticles

This article has been cited by 28 article(s) on the ISI Web of Science.

This article has been cited by 5 articles hosted by HighWire Press; see:

http://www.sciencemag.org/cgi/content/full/314/5798/479\#otherarticles

This article appears in the following subject collections:

Ecology

http://www.sciencemag.org/cgi/collection/ecology

Information about obtaining reprints of this article or about obtaining permission to reproduce this article in whole or in part can be found at:

http://www.sciencemag.org/about/permissions.dtl 


\section{Long-Term Sustainability of a High-Energy, Low-Diversity Crustal Biome}

Li-Hung Lin, ${ }^{1,2 *}$ Pei-Ling Wang, ${ }^{3}$ Douglas Rumble, ${ }^{4}$ Johanna Lippmann-Pipke, ${ }^{5}$ Erik Boice, ${ }^{6}$ Lisa M. Pratt, ${ }^{6}$ Barbara Sherwood Lollar, ${ }^{7}$ Eoin L. Brodie, ${ }^{8}$ Terry C. Hazen, ${ }^{8}$ Gary L. Andersen, ${ }^{8}$ Todd Z. DeSantis, ${ }^{8}$ Duane P. Moser, ${ }^{9}$ Dave Kershaw, ${ }^{10}$ T. C. Onstott ${ }^{1}$

Geochemical, microbiological, and molecular analyses of alkaline saline groundwater at 2.8 kilometers depth in Archaean metabasalt revealed a microbial biome dominated by a single phylotype affiliated with thermophilic sulfate reducers belonging to Firmicutes. These sulfate reducers were sustained by geologically produced sulfate and hydrogen at concentrations sufficient to maintain activities for millions of years with no apparent reliance on photosynthetically derived substrates.

$\mathrm{M}$ ost subsurface microbial ecosystems examined to date (including subseafloor sediments, deep-sea hydrothermal vents, terrestrial sedimentary aquifers, and petroleum reservoirs) ultimately depend on sunlight. These studies have been mostly confined to depths of less than $1 \mathrm{~km}$, and the ecosystems are either supported by photosynthetically produced electron donors and acceptors transported by groundwater or seawater with ages much less than a million years, or are in constant contact with oxygenated seawater migrating through the underlying fractured basaltic aquifer (1-4). Although two occurrences of autotrophic microbial communities have been reported to exist in $<300$-m-deep volcanic aquifers flushed with fresh meteoric water $(5,6)$, their long-term sustainability on $\mathrm{H}_{2}$ and isolation from photosynthetically produced substrates have not been demonstrated. Although the existence of subsurface microorganisms at depths greater than $1 \mathrm{~km}$ in pristine environments is well established (7), much is still unknown regarding the abundance, diversity, and sustainability of these microbial communities over geological time scales.

To determine the long-term sustainability of a deep terrestrial environment, we examined the microbial diversity and metabolic activity of a 3-to 4-km-deep fracture in the 2.7-billion-year-old Ventersdorp Supergroup metabasalt, in which fracture water ages of tens of millions of years (8), abundant abio-

${ }^{1}$ Department of Geosciences, Princeton University, Princeton, N], USA. ${ }^{2}$ Department of Geosciences, ${ }^{3}$ Institute of Oceanography, National Taiwan University, Taipei, Taiwan. ${ }^{4} \mathrm{Geo}$ physical Laboratory, Carnegie Institution of Washington, Washington, DC, USA. ${ }^{5}$ GeoForschungsZentrum Potsdam, Telegrafenberg, Potsdam, Germany. ${ }^{6}$ Department of Geological Sciences, Indiana University, Bloomington, IN, USA ${ }^{7}$ Department of Geology, University of Toronto, Toronto, ON, Canada. ${ }^{8}$ Ecology Department, Lawrence Berkeley National Laboratory, Berkeley, CA, USA. ${ }^{9}$ Division of Earth and Ecosystems Sciences, Desert Research Institute, Las Vegas, NV, USA. ${ }^{10}$ Mponeng Mine, Anglo Gold, Johannesburg, South Africa.

*To whom correspondence should be addressed. E-mail: Ihlin@ntu.edu.tw

genic hydrocarbons (9), and radiolytically produced $\mathrm{H}_{2}$ (10) have been reported. To characterize the indigenous microbial composition and its principal respiratory pathway, we analyzed $16 S$ ribosomal DNA (rDNA) $\mathrm{Ma}$, million years ago.
Sample no. (number of days
since intersection)

Sample name

Origin

Water and gas flow rates

(liters $\min ^{-1}$ ) (borehole volumes)

$\mathrm{pH}$

$E_{\mathrm{h}}(\mathrm{mV})$

Temperature $\left({ }^{\circ} \mathrm{C}\right)$

Formate $(\mu \mathrm{M}) \|$

Acetate $(\mu \mathrm{M}) \|$

$\mathrm{Cl}^{-}(\mathrm{mM})^{*} \|$

$\mathrm{Br}^{-}(\mu \mathrm{M}) \|$

$\mathrm{SO}_{4}{ }^{2-}(\mu \mathrm{M}) \|$

$\mathrm{HS}^{-}(\mu \mathrm{M})+\|$

$\mathrm{H}_{2}(\mu \mathrm{M}) \dagger \|$

$\mathrm{CH}_{4}(\mu \mathrm{M})+\|$

$\mathrm{O}_{2}(\mu \mathrm{M}) \ddagger \|$

$\delta^{2} \mathrm{H}-\mathrm{H}_{2}$ (\%o VSMOW)

$\delta^{13} \mathrm{C}^{-\mathrm{CH}_{4}}$ (\%) PDB)§॥

$\delta^{2} \mathrm{H}-\mathrm{CH}_{4}$ (\%o VSMOW)\|

${ }^{4} \mathrm{He}$ model age (Ma)

${ }^{40} \mathrm{Ar}$ model age $(\mathrm{Ma})$

${ }^{134} \mathrm{Xe}$ model age $(\mathrm{Ma})$

${ }^{136} \mathrm{Xe}$ model age (Ma)

Bacterial DNA (pg ml${ }^{-1}$ )

Archaeal DNA (pg ml ${ }^{-1}$ ) and $\delta^{2} \mathrm{H}-\mathrm{H}_{2}$.
Table 1. Geochemical and microbiological characteristics of fracture water and mining water. NA, not available; <d.l., below detection limit, which is $1 \mu \mathrm{M}$ for $0_{2}$ and $0.5 \mathrm{fg} \mathrm{ml}^{-1}$ for archaeal DNA;

Cell density (cells $\mathrm{ml}^{-1}$ )
$1(4)$

$2(7)$

$\begin{array}{lllll}\text { MP104E65X } & \text { MP104E65X } & \text { MP104E65X } & \text { MP104E65X } & \text { MP104E65XC- } \\ \text { C-091602 } & \text { C-091902 } & \text { C-092702 } & \text { C-110902 } & \text { SW-091602 } \\ \text { Fracture } & \text { Fracture } & \text { Fracture } & \text { Fracture } & \text { Mining } \\ \quad \text { water } & \text { water } & \text { water } & \text { water } & \text { water } \\ \text { 40/2.4 (45) } & 10.9 / 0.8(55) & 8.2 / 1.2(64) & 2.3 / 1.7(96) & \text { NA }\end{array}$

$40 / 2.4(45)$

$10.9 / 0.8$

(55) $8.2 / 1.2(64)$ sequences, aqueous and gas geochemistry, and stable and noble gas isotopic signatures of moderately saline groundwater emanating from a fracture zone $2.825 \mathrm{~km}$ below the mine, South Africa. This high-pressure waterbearing fracture was intersected during exploratory drilling ahead of a tunnel advancing into an unmined zone $\sim 100 \mathrm{~m}$ above the Ventersdorp Contact Reef (VCR) ore zone. The fracture water was initially sampled as soon as it was safe to do so (4 days after the fracture intersection), and three subsequent samples were obtained over a 54-day interval (Table 1) to monitor drilling contamination and possible changes of community structure and geochemistry as the fracture was dewatered and before being sealed by the mine's cementation team.

Fracture water samples yielded a uniform community structure dominated by a single phylotype (MP104-0916-b1) that constituted land surface (kmbls) in the Mponeng gold

*The concentrations derived from charged balance were $10.2 \mathrm{mM}$ for sample 1, $27.6 \mathrm{mM}$ for sample 3 and $50.6 \mathrm{mM}$ for sample 4 . †The concentrations of dissolved gases were reported as concentrations corrected for diffusive loss (8). Diffusive correction was not applied to sample 4 because of the lack of noble gas analysis. $\quad$ The positive $\mathrm{O}_{2}$ content for sample 1 may be derived from incomplete isolation of fracture water from the mining environment caused by the extremely high water pressure and flow rate. $\S_{\text {The carbon }}$ isotopic value was referenced to Pee Dee belemnite (PDB). IIThe uncertainties for aqueous and gas chemistry are $\pm 10 \%$ and $\pm 20 \%$, respectively. The uncertainties for isotopic measurements are $\pm 0.5 \%$ for $\delta^{13} \mathrm{C}$-hydrocarbon and $\pm 5 \%$ for $\delta^{2} \mathrm{H}$-hydrocarbon 
Fig. 1. Phylogenetic trees for bacteria (A) and archaea (B) based on 165 rDNA sequences recovered from fracture and mining water in the Mponeng gold mine, South Africa. The fraction number in parentheses represents the number of clones for each phylotype versus the total number of clones analyzed in each sample. The scale bar is equivalent to the sequence variation of $10 \%$.
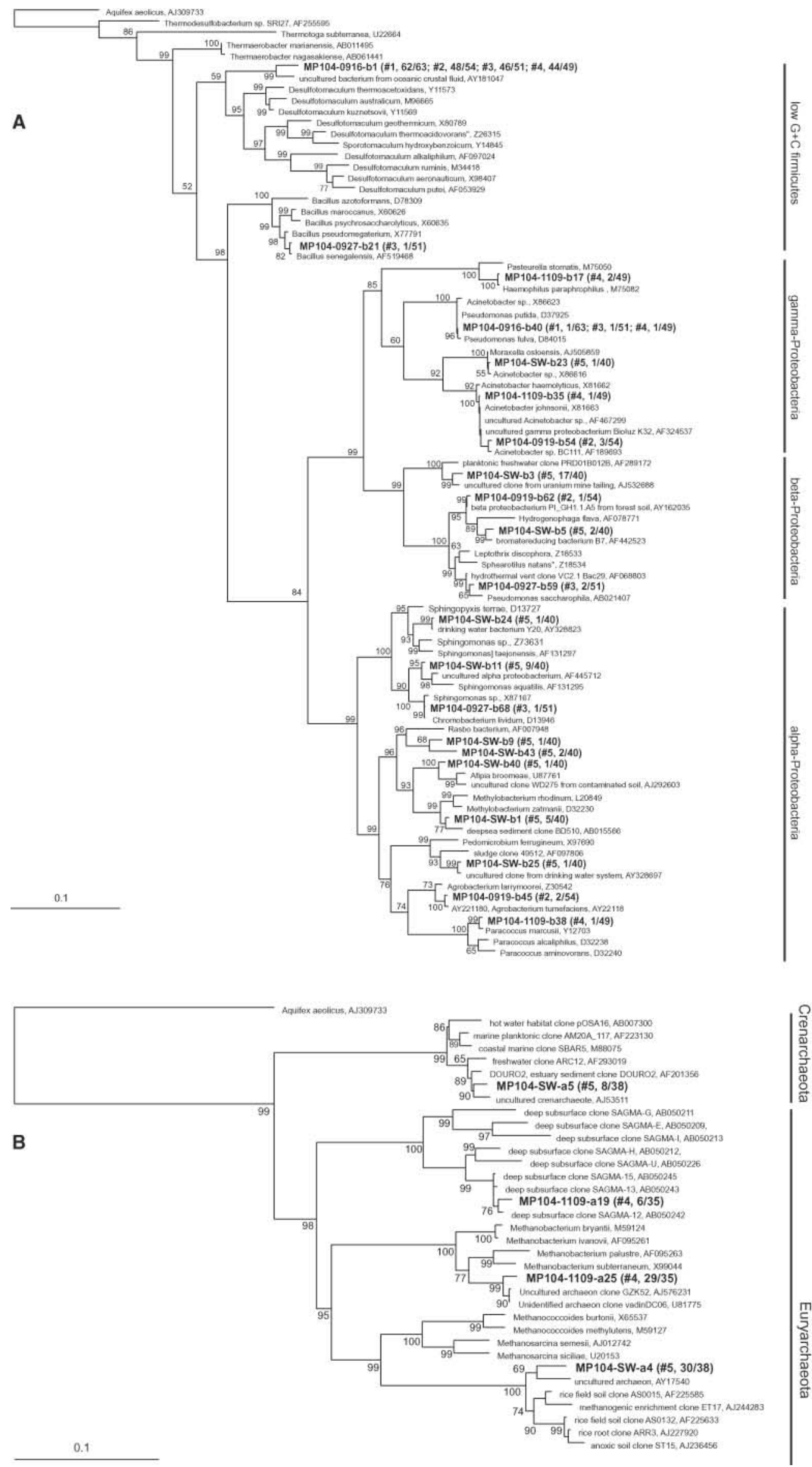
$>88 \%$ of the clones in the $16 S \mathrm{rDNA}$ libraries we generated but did not appear in the water used for mining (Fig. 1A). This phylotype was related ( $96 \%$ similarity) to an uncultured clone recovered from thermal fluids of oceanic crust (11) or to Desulfotomaculum kuznetsovii (91\% similarity) (12), a sulfate reducer growing at moderately thermophilic conditions. Of the other minor bacterial and archaeal phylotypes associated with the fracture water, MP104-1109-a19 resembled (98\% similarity) environmental clones (the SAGMEG-2 group) obtained from fracture water in an adjacent mine (13) (Fig. 1B). Other phylotypes were closely related (98 to $99 \%$ similarity) to environmental clones recovered from surface environments (such as soils and sludge) or to various mesophiles distributed within Proteobacteria, Firmicutes, and Methanobacteria (Fig. 1). These minor phylotypes did not resemble those from the mining water [see supporting online material (SOM)].

High-density $16 S$ rDNA microarray analysis was also used as a more sensitive approach to assess microbial diversity. Array hybridization results supported the finding that microbial diversity was much less (table S2) and the Firmicutes were of greater relative abundance (table S3) in the fracture water than in the mining water. Some overlap between the sequences found in the fracture water and those in the mining water is expected because mining water is a mixture of recycled fracture water and surface water.

The geochemistry of the fracture water was characterized to identify its origin and to assess the principal metabolic pathways (Table 1 and tables S1 and S4). Over the observation period, the temperature decreased from $>60^{\circ}$ to $52^{\circ} \mathrm{C}$, while the $\mathrm{pH}$ was constant and the redox potential $\left(E_{\mathrm{h}}\right)$ increased from -330 to $-263 \mathrm{mV}$. The $\mathrm{Cl}^{-}, \mathrm{Br}^{-}$, and $\mathrm{SO}_{4}^{2-}$ concentrations increased significantly, whereas other anion concentrations fluctuated or decreased slightly. Reduced gases $\left(\mathrm{H}_{2}\right.$ and $\left.\mathrm{CH}_{4}\right)$ were abundant $(>1 \mathrm{mM})$, and their concentrations increased as water flow rates declined and gas flow rates remained constant. Formate and acetate concentrations ranged from 7 to $9 \mu \mathrm{M}$ and 22 to $36 \mu \mathrm{M}$, respectively. The $\delta^{2} \mathrm{H}$ and $\delta^{13} \mathrm{C}$ of the abundant dissolved $\mathrm{C}_{1-4}$ hydrocarbons indicated an abiogenic origin, based on their similarity to abiogenic hydrocarbon gases identified at other Precambrian Shield sites (9). The $\delta^{2} \mathrm{H}$ and $\delta^{18} \mathrm{O}$ values of the fracture water, -29.1 per mil (\%) and $-6.9 \%$ VSMOW (Vienna standard mean ocean water), respectively, plotted slightly above the global and local meteoric line (14). The $\delta^{2} \mathrm{H}-\mathrm{H}_{2}$ values ranged between -680 and $-690 \%$ VSMOW, which when compared with the $\delta^{2} \mathrm{H}-\mathrm{H}_{2} \mathrm{O}$ value yielded isotopic equilibrium temperatures of $62^{\circ} \mathrm{C}$ for the first sample, declining to $49^{\circ} \mathrm{C}$ for the last sample. Based on the thermal conductivity model (15) and the heat flow data (16), the initial temperature equates to that at $4.2 \mathrm{kmbls}$ and the final temperature to that at $2.9 \mathrm{kmbls}$.

Noble gas analyses yielded elevated radiogenic and fissiogenic concentrations of ${ }^{4} \mathrm{He}$, ${ }^{40} \mathrm{Ar},{ }^{134} \mathrm{Xe}$, and ${ }^{136} \mathrm{Xe}$ (table S1) but exhibited no systematic trend during the observation period. The bulk model age of the fracture water ranged from $15.8 \pm 7.9$ million years to $25.0 \pm$ 3.8 million years (Table 1 ). This model age represents either the true subsurface residence time or the mixing between a hydrothermal fluid that is ancient ( 0.8 to 2.5 billion years old); saline; and $\mathrm{H}_{2}-\mathrm{C}_{1-4}$ hydrocarbon-, and $\mathrm{SO}_{4}{ }^{2-}$-rich; and paleometeoric water that is $\sim 3$ to 4 million years old; moderately saline; and $\mathrm{H}_{2}-, \mathrm{C}_{1-4}$ hydrocarbon- and $\mathrm{SO}_{4}{ }^{2-}$ poor (SOM).

The exceptional dominance of the Firmicutes clones; $\delta^{2} \mathrm{H}$ and $\delta^{18} \mathrm{O}$ values of the fracture water that are distinct from those of the mining water (17); and increasing $\mathrm{H}_{2}, \mathrm{CH}_{4}$, $\mathrm{He}, \mathrm{Cl}^{-}, \mathrm{Br}^{-}$, and $\mathrm{SO}_{4}{ }^{2-}$ concentrations during the observation period suggest that the fracture environment favors the survival of these Firmicutes-related microorganisms and that mining operations had minimal impact on this environment during depressurization and dewatering. Desulfotomaculum-related environmental clones and isolates have been detected in other subsurface environments, including an oil reservoir (18), deep sedimentary strata $(19,20)$, an ore deposit $(21)$, and saline water emanating from a $3.2-\mathrm{kmbls}$ borehole located $13 \mathrm{~km}$ east of this borehole (22). The evident success of these microorganisms may not be surprising because their ability to form endospores would facilitate their survival during periods of low water activity, nutrient deprivation, and suboptimal temperature (23). Whether the less abundant members of the clone libraries represent indigenous microorganisms that are capable of acquiring energy through metabolisms that are distinct from those of the strains they most resemble phylogenetically, or alternatively represent moribund relics of shallower, less saline paleometeoric water that has mixed with this fracture water, is not known.

Sulfur isotopic analyses yielded $\delta^{34} \mathrm{~S}$ values of $\mathrm{HS}^{-}$ranging from 11 to $13 \%$ Vienna Canon Diablo meteorite (VCDT) and those of $\mathrm{SO}_{4}{ }^{2-}$ from 19 to $26 \%$ VCDT (table S4). The depleted $\delta^{34} \mathrm{~S}$ value of $\mathrm{HS}^{-}$relative to that of $\mathrm{SO}_{4}^{2-}(-7.7 \%$ o for sample 4 and $-12.4 \%$ o for sample 7) is consistent with microbial sulfate reduction. The fact that $\mathrm{SO}_{4}{ }^{2-}$ concentrations in the fracture water were higher than that of the overlying dolomitic aquifer (13), and that $\mathrm{SO}_{4}{ }^{2-}$ has been reported in analyses of fluid inclusions from hydrothermal quartz in the VCR (24) and the reservoir mixing-fractionation model (SOM), all suggest that the $\mathrm{SO}_{4}{ }^{2-}$ originated from the ancient hydrothermal fluid, not the paleometeoric end member. The $\delta^{34} \mathrm{~S}$ values of fracture pyrite ( 0 to $2 \%$ VCDT) were less than that of the coexisting barite $(10.1 \%$ VCDT) (table S4) and were consistent with those of hydrothermal 2.0-billion-year-old pyrite from the VCR in the same mine (25). The $\Delta^{33} \mathrm{~S}$ values for all samples clustered around $0 \%$ (table S4). To reproduce the $\Delta^{33} \mathrm{~S}$ of total dissolved $\mathrm{S}$ species $(-0.022 \%$ ) for sample 7 , a mixing of $\mathrm{SO}_{4}^{2-}$ derived from

Table 2. Gibbs free energy $(\Delta G)$, substrate consumption rate and steady-state free-energy flux for various microbial redox reactions.

Sample no.

1

3

4

$\Delta G \quad$ Substrate rate* Energy flux* $\Delta G \quad$ Substrate rate* Energy flux* $\Delta G \quad$ Substrate rate* Energy flux

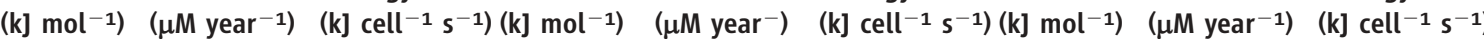

\begin{tabular}{|c|c|c|c|c|c|c|c|c|c|}
\hline $\mathrm{H}_{2}$-sulfate reduction $† \ddagger$ & -148 & $5.9 \times 10^{6}$ & $-9.2 \times 10^{-13}$ & -155 & $8.6 \times 10^{6}$ & $-1.4 \times 10^{-12}$ & -146 & $1.8 \times 10^{7}$ & $-2.7 \times 10^{-12}$ \\
\hline Acetate-sulfate reduction $† \ddagger$ & -86 & $1.9 \times 10^{5}$ & $-1.7 \times 10^{-14}$ & -94 & $1.5 \times 10^{5}$ & $-1.5 \times 10^{-14}$ & -82 & $2.4 \times 10^{5}$ & $-2.1 \times 10^{-14}$ \\
\hline $\mathrm{H}_{2}$-methanogenesis $\ddagger$ & -94 & $2.1 \times 10^{5}$ & $-2.1 \times 10^{-14}$ & -95 & $2.9 \times 10^{4}$ & $-2.9 \times 10^{-15}$ & -93 & $3.8 \times 10^{5}$ & $-3.7 \times 10^{-14}$ \\
\hline Acetate-methanogenesis $\ddagger$ & -33 & $1.9 \times 10^{5}$ & $-6.6 \times 10^{-15}$ & -34 & $1.5 \times 10^{5}$ & $-5.5 \times 10^{-15}$ & -28 & $2.4 \times 10^{5}$ & $-7.1 \times 10^{-15}$ \\
\hline Formate-methanogenesis $\ddagger$ & -74 & $1.8 \times 10^{4}$ & $-1.4 \times 10^{-15}$ & -86 & $1.5 \times 10^{4}$ & $-1.3 \times 10^{-15}$ & -42 & $1.8 \times 10^{3}$ & $-8.1 \times 10^{-17}$ \\
\hline $\mathrm{H}_{2}$-acetogenesis $\ddagger$ & -62 & $1.4 \times 10^{5}$ & $-9.3 \times 10^{-15}$ & -61 & $2.0 \times 10^{4}$ & $-1.2 \times 10^{-15}$ & -64 & $2.5 \times 10^{5}$ & $-1.7 \times 10^{-14}$ \\
\hline
\end{tabular}

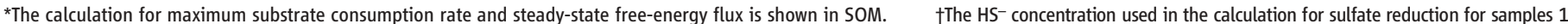

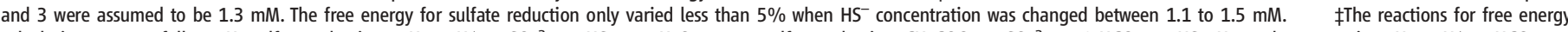

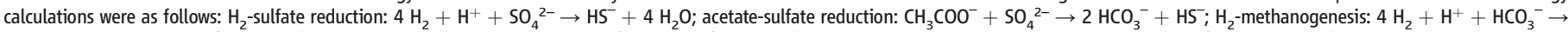

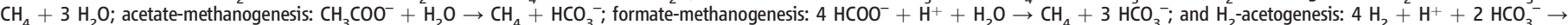
$\mathrm{CH}_{3} \mathrm{COO}^{-}+4 \mathrm{H}_{2} \mathrm{O}$. The uncertainties are $\pm 10 \%$. 
pyrite oxidation and barite dissolution with a Rayleigh isotopic fractionation by microbial sulfate reduction was required (SOM). Such a mixture, composed of $30 \% \mathrm{SO}_{4}{ }^{2-} \mathrm{de}-$ rived from the oxidation of pyrite by radiolytically produced oxidants (10) and 70\% $\mathrm{SO}_{4}{ }^{2-}$ derived from the dissolution of barite, produced an initial $\delta^{34} \mathrm{~S}$ value of $8.13 \%$ VCDT and a $\Delta^{33} \mathrm{~S}$ value of $-0.0087 \%$ (SOM). The isotopic evolution from the initial 8.13\% VCDT to the present observation (18.63\% VCDT for total dissolved $\mathrm{S}$ species) requires a Rayleigh fractionation process in which $70 \%$ of the initial $\mathrm{SO}_{4}{ }^{2-}$ was removed as microbially precipitated pyrite (SOM). By this model, the total $\mathrm{HS}^{-}$formed by microbial sulfate reduction would be $4.35 \mathrm{mM}[1.52 \mathrm{mM} \times$ $70 \% / 30 \%+0.80 \mathrm{mM} \mathrm{HS}^{-}$(SOM)].

The Gibbs free energy for microbial redox reactions was calculated to provide additional constraints on the dominant respiratory pathway occurring in this fracture water. Sulfate reduction dominated the free-energy yields for a wide range of electron donor and acceptor combinations (Table 2). The freeenergy yields for these reactions were much greater than the minimum requirement for synthesis of $1 / 3$ of an adenosine triphosphate molecule by pumping one proton across the cell membrane ( $\sim-20 \mathrm{~kJ})(26)$. Among electron donors available for sulfate reduction and methanogenesis, $\mathrm{H}_{2}$ yielded more free energy than acetate and formate, and $\mathrm{H}_{2}$ utilizing sulfate reduction yielded the highest free energy and energy flux (Table 2), suggesting that $\mathrm{CO}_{2}$-utilizing methanogens and acetogens cannot sustain as high a population density as sulfate reducers and therefore would be minor constituents of the community, as is observed in the clone libraries. The prominence of the free-energy flux for $\mathrm{H}_{2}$-utilizing sulfate reduction over other metabolic reactions is consistent with the depletion of $\delta^{34} \mathrm{~S}$ values of $\mathrm{HS}^{-}$relative to $\mathrm{SO}_{4}{ }^{2-}$ (27) and the physiological characteristics inferred from the dominant phylotype.

The in situ rate of microbial sulfate reduction was estimated to range from 0.22 to 1.45 $\mathrm{nM}$ year $^{-1}$, or from $5.5 \times 10^{-18}$ to $3.6 \times$ $10^{-17}$ moles per cell year ${ }^{-1}$ (assuming that all observed cells, $4 \times 10^{7}$ cells liter $^{-1}$, actively reduce $\mathrm{SO}_{4}{ }^{2-}$ ), based on the potential microbially produced sulfide $[4.35 \mathrm{mM}(\mathrm{SOM})]$ and fracture water residence time of $\sim 3$ or $\sim 20$ million years inferred from noble gas analysis. Such a rate is comparable to rates reported in subseafloor sediments (28) and to the estimated rate of radiolytic $\mathrm{H}_{2}$ generation (10), but far less (4 to 5 orders of magnitude) than the maintenance energy demand of mesophilic sulfate reducers as determined in laboratory experiments (29) (SOM). The estimated in situ sulfate reduction rate, when combined with the experimental maintenance energy demand $[48 \mathrm{~mol} \text { ( } \mathrm{g} \text { dry weight cell })^{-1}$ year $^{-1}$ ] (29) and assuming 20 fg per cell, would support only 200 to 1600 cells liter $^{-1}$, which is far below the observed $\sim 4 \times 10^{7}$ cells liter $^{-1}$. If cells were constantly growing and dying, then the experimental sulfate reducer yield of $12.2 \mathrm{~g}$ of dry weight cell $\mathrm{mol}^{-1}$ (29), when combined with the in situ sulfate reduction rate, would correspond to cell turnover times of 45 to 300 years. The isotopic estimate of the long-term in situ microbial activity, however, is $10^{9}$ to $10^{10}$ times less than the maximum substrate consumption rate (Table 2), which would seem to indicate that as-yet-unidentified factors play a role in restraining the microbial respiration.

The hot, reducing, gaseous water emanating from a fracture at 2.8 to $4.2 \mathrm{kmbls}$ harbored a microbial community dominated by a single Firmicutes phylotype. The Firmicutes probably penetrated the Mponeng fracture zone at current depths during infiltration of paleometeoric water between 3 and 25 million years ago and since then have relied on nonphotosynthetically derived $\mathrm{H}_{2}$ and $\mathrm{SO}_{4}{ }^{2-}$ converted from Archaean/Proterozoic pyrite/barite. Nutrient concentrations have remained much higher than observed in shallower crustal environments, suggesting that the deep crustal biosphere may be energy-rich, is not approaching entropic death, and is capable of sustaining microbial communities indefinitely by geological processes.

\section{References and Notes}

1. K. O. Stetter et al., Nature 365, 743 (1993).

2. D. M. Karl, in The Microbiology of Deep-Sea Hydrothermal Vents, D. M. Karl, Ed. (CRC Lewis, Boca Raton, FL, 1995), pp. 35-124.

3. E. M. Murphy et al., Water Res. Res. 28, 723 (1992).

4. S. D'Hondt et al., Science 306, 2216 (2004).

5. F. H. Chapelle et al. Nature 415, 312 (2002).

6. T. O. Stevens, ]. P. McKinley, Science 270, 450 (1995).

7. T. C. Onstott et al., in Enigmatic Microorganisms and Life in Extreme Environments, ]. Seckbach, Ed. (Kluwer Academic, Dordrecht, Netherlands, 1999), pp. 489-500.

8. J. Lippmann et al., Geochim. Cosmochim. Acta 67, 4597 (2003).

9. B. Sherwood Lollar et al., Chem. Geol. 226, 328 (2006).
10. L. H. Lin et al., Geochem. Geophys. Geosyst. 6, Q07003 10.1029/2004GC000907 (2005).

11. J. P. Cowen et al., Science 299, 120 (2003).

12. T. N. Nazina, A. E. Ivanova, L. P. Kanchaveli, E. P. Rozanova, Mikrobiologiya 57, 823 (1988).

13. K. Takai, D. P. Moser, M. DeFlaun, T. C. Onstott, J. K. Fredrickson, Appl. Environ. Microbiol. 67, 5750 (2001).

14. H. Craig, Science 133, 1702 (1961).

15. G. Omar, T. C. Onstott, ]. Hoek, Geofluids 3, 69 (2003).

16. M. Q. W. Jones, J. Geophys. Res. 93, 3243 (1988).

17. G. R. Drennan, M. C. Boiron, M. Cthelineau, L. ]. Robb, Mineral. Petrol. 66, 83 (1999).

18. C. Tardy-Jacquenod, M. Magot, B. K. Patel, R. Matheron, P. Caumette, Int. J. Syst. Bacteriol. 48, 333 (1998).

19. H. Saas, H. Cypionka, Syst. Appl. Mcirobiol. 27, 541 (2004).

20. Y. Liu et al., Int. J. Syst. Bacteriol. 47, 615 (1997).

21. T. Nakagawa et al., FEMS Microbiol. Ecol. 41, 199 (2002).

22. D. P. Moser et al., Gemicrobiol. J. 20, 517 (2003).

23. L. L. Campbell, R. Singleton, in Bergey's Manual of Systematic Bacteriology, P. H. A. Sneath, N. S. Mair M. E. Sharpe, ]. G. Holt, Eds. (Williams \& Wilkins, Baltimore, MD, 1986), vol. 2, pp. 1200-1202.

24. H. E. Frimmel, D. K. Hallbauer, V. H. Gartz, Mineral. Petrol. 66, 55 (1999).

25. B. Zhao, C. Harris, L. J. Jordaan, L. J. Robb, Geosci. Afr. 2004 2, 732 (2004)

26. B. Schink, Microbiol. Mol. Biol. Rev. 61, 262 (1997).

27. A. L. W. Kemp, H. G. Thode, Geochim. Cosmochim. Acto 32, 71 (1968).

28. R. J. Parkes et al., Nature 436, 390 (2005).

29. W. Badziong, R. K. Thauer, Arch. Microbiol. 117, 209 (1978).

30. This work was supported by grants from NSF Life in Extreme Environments and NASA to T.C.O.; the National Science Council of Taiwan to L.-H.L. and P.-L.W.; the Jet Propulsion Laboratory, NASA Cosmochemistry, and NSF Earth Science to D.R.; the Deutsche Forschungsgemeinschaft (German Research Foundation) to ].L.-P.; the NASA Indiana-Princeton-Tennessee Astrobiology Initiative to L.P.; the National Science and Engineering Research Council of Canada and Killam Fellowship funds to B.S.L. and the U.S. Department of Energy to T.C.H. We thank ]. Hall, G. Southam, G. Wagner, B. Tipple, T. Gihring, E. Van Heerden, and D. Litthauer of the Witwatersrand Microbiology Project, R. Wilson of SRK-Turgis Technology, and geologists of the Mponeng mine for their assistance in the setup of the field laboratory, field sampling, and the coordination of logistic supply. We also acknowledge D. Chivian for discussion of DNA data and S. Ono for assisting with sulfur isotope analysis. GenBank accession numbers for sequences are from DQ088779 to DQ088817.

\section{Supporting Online Material}

www.sciencemag.org/cgi/content/full/314/5798/479/DC1

SOM Text

Figs. S1 and S2

Tables S1 to S4

References

13 March 2006; accepted 21 September 2006

10.1126/science. 1127376 